\title{
Gendered dimensions of obesity in childhood and adolescence Helen N Sweeting
}

\author{
Address: MRC Social and Public Health Sciences Unit, 4, Lilybank Gardens, Glasgow, G12 8RZ, UK \\ Email: Helen N Sweeting - helen@sphsu.mrc.ac.uk
}

Published: 14 January 2008

Nutrition Journal 2008, 7:1 doi:10.1/86/1475-289|-7-1

This article is available from: http://www.nutritionj.com/content/7/I/I

(c) 2008 Sweeting; licensee BioMed Central Ltd.

This is an Open Access article distributed under the terms of the Creative Commons Attribution License (http://creativecommons.org/licenses/by/2.0), which permits unrestricted use, distribution, and reproduction in any medium, provided the original work is properly cited.
Received: 15 March 2007

Accepted: 14 January 2008

\begin{abstract}
Background: The literature on childhood and adolescent obesity is vast. In addition to producing a general overview, this paper aims to highlight gender differences or similarities, an area which has tended not to be the principal focus of this literature.

Methods: Databases were searched using the terms 'obesity' and 'child', 'adolescent', 'teenager', 'youth', 'young people', 'sex', 'gender', 'masculine', 'feminine', 'male', 'female', 'boy' and 'girl' (or variations on these terms). In order to limit the potential literature, the main focus is on other reviews, both general and relating to specific aspects of obesity.

Results: The findings of genetic studies are similar for males and females, and differences in obesity rates as defined by body mass index are generally small and inconsistent. However, differences between males and females due to biology are evident in the patterning of body fat, the fat levels at which health risks become apparent, levels of resting energy expenditure and energy requirements, ability to engage in certain physical activities and the consequences of obesity for the female reproductive system. Differences due to society or culture include food choices and dietary concerns, overall physical activity levels, body satisfaction and the long-term psychosocial consequences of childhood and adolescent obesity.
\end{abstract}

Conclusion: This review suggests differences between males and females in exposure and vulnerability to obesogenic environments, the consequences of child and adolescent obesity, and responses to interventions for the condition. A clearer focus on gender differences is required among both researchers and policy makers within this field.

\section{Introduction}

The 'epidemic' of childhood and adolescent obesity has spawned a similar epidemic of research publications. These include many excellent reviews, produced for both clinical and epidemiological audiences (e.g. [1-3]). As an indication of the scale of the literature, Medline and Web of Science searches (September 2007) using the terms (or variations on terms) 'obesity' and ('child' or 'adolescent' or 'teenager' or 'youth' or 'young people') and limited to 1996-2007 English language publications, produced
11,280 and 9,067 hits respectively; addition of the term 'review' reduced the numbers to 1,991 and 552.

This paper reviews obesity in childhood and adolescence, but with a special focus on differences between males and females. These may result from differences in biology (sex differences) or those assumed to be due to society or culture (gender differences), or a combination of the two $[4,5]$. Both sex and gender are relevant to obesity. It is a product of, and impacts upon, both biology and behavior, and is associated with socially constructed attitudes and 
beliefs. Given the relevance of both sex and gender, a problem arises as to how to describe differences between males and females. To use the term 'gender difference' to describe purely biological differences is to misapply it [4], however to use 'sex' and 'gender' differences interchangeably because they cannot be entirely separated [6] is confusing and fails to address the issue. Here, the term 'gender' is used, since the majority of differences are unlikely to have solely biological origins.

Given this focus, databases including Medline, Embase, Web of Knowledge, Psychinfo and Cinahl were searched using the terms described above together with 'sex', 'gender', 'masculine', 'feminine', 'male', 'female', 'boy' and 'girl' (or variations on these terms). The aim was not simply to identify literature on differences between males and females, but also to investigate whether there was evidence of differences within what has been described as the 'gender/sex dichotomy' [5]. After reviewing the resulting titles and/or abstracts, it was decided to focus in the main on other reviews, both general and relating to specific aspects of obesity, in order to limit the vast potential literature. However, it should be recognized that reviews, particularly conventional narrative reviews, may be subject to errors in both data handling and reporting [7]. An exception to the use of review papers was made in respect of the sub-section on 'Distribution of obesity as defined by BMI', because to do so would have meant that results from individual studies of rates among males and females could not be presented.

The sections which follow this introduction describe definitions and distribution, causes, consequences and interventions for child and adolescent obesity. Gender differences, when identified, are highlighted.

\section{Definitions and distribution} Definitions and measurement

Obesity can be defined as a pathological excess of body fat $[1,2,8,9]$. However, fat is not homogeneous, and abdominal fat has emerged as most clinically relevant [10]. Differences between males and females in adult body fat have long been recognized, the android, male, fat pattern represented by relatively greater fat in the upper body, the gynoid, female, pattern by relatively greater amounts in the hip and thigh areas [11]. Body fat distribution is partially hormonally controlled, and differences between males and females in fat mass have generally been considered to become manifest during puberty $[1,12]$. However, recent studies of pre-pubertal children have also found higher levels of fat and evidence of the gynoid pattern among females at much younger ages [13]. Studies which have assessed the degree of body fat associated with significantly elevated cardiovascular risk factors in children and adolescents, suggest that health risks become evident at lower levels for males than females [13].

Given its association with health risks, it has been suggested that there should be a greater emphasis than is current on the assessment of fat, particularly abdominal fat, for both clinical and epidemiological purposes [14]. However, the most accurate measures of body fatness are generally expensive, require laboratory conditions and/or are associated with reduced participant acceptability. Most epidemiological studies therefore rely on anthropometry, which can include measurements of skinfolds, or of waist and hip circumferences representing abdominal fat. The most frequently used measure is weight in relation to height, usually represented by the body mass index (BMI), defined as weight $(\mathrm{kg}) /$ height squared $\left(\mathrm{m}^{2}\right)[13]$.

BMI has, despite many recognized limitations [15], been described as crucial to obesity classification and monitoring [14]. Given appropriate cut-offs, it can be used to classify obese children and adolescents with high specificity, thus identifying few false positives [16]. However, BMI varies according to both gender and age, and much less is known about specific BMI levels associated with health risks among children and adolescents than among adults [8]. BMI-for-age gender-specific reference charts with recommended cut-offs defining obesity have been developed in a number of countries. In addition, the International Obesity task Force (IOTF) has produced charts based on pooled international data using centile curves based on the recommended definitions of adult overweight and obese, aiming to compare across populations and employ a consistent definition throughout the lifespan [17-19]. Although the majority of studies adopt one or other of these definitions, alternative cut-offs continue to be used [20], but with decreasing frequency. The range of definitions means that it is often difficult to compare obesity rates between studies, because the methods used impact on the proportion of children defined as obese $[13,21]$.

\section{Distribution of obesity as defined by BMI}

Table 1, which shows obesity rates at several time points and in a large number of different countries, demonstrates the impact of different definitions.

Despite different definitions, the wide range in prevalences between countries is clear. This was also seen in a study of European, Israeli and US adolescents, who selfreported height and weight in 1997-98. These data are not shown in Table 1 since the definition was not 'standard', being the $95^{\text {th }} \mathrm{BMI}$ centile for age and gender derived for the whole sample. Overall rates were therefore around $5 \%$, with the lowest rates in Lithuania, and the highest in the United States [22]. Very similarly, a comparison of obesity prevalence, based on the IOTF definition among 
Table I: Examples of international obesity rates; different definitions, ages and dates - males and females

\begin{tabular}{|c|c|c|c|c|c|c|c|}
\hline Country & Survey/data & Definition & Age(s) & Date(s) & $\begin{array}{c}\% \\
\text { males }\end{array}$ & $\begin{array}{c}\% \\
\text { females }\end{array}$ & Reference \\
\hline \multicolumn{8}{|l|}{ North America } \\
\hline \multirow[t]{4}{*}{ United States } & $\begin{array}{l}\text { National Health and } \\
\text { Nutrition Examination } \\
\text { Surveys }\end{array}$ & $\begin{array}{l}\text { US National Center for } \\
\text { Health Statistics (1979) } \\
\text { weight for length (children } \\
\text { younger than 3) and } \\
\text { weight for stature curves > } \\
95^{\text {th }} \text { percentile }\end{array}$ & $<1$ & $1976-80$ & 4.0 & 6.2 & $\begin{array}{c}\text { Ogden, Troiano \& } \\
\text { Briefel et al, } 1997 \\
\text { [134] }\end{array}$ \\
\hline & & & & 1988-94 & 7.5 & 10.8 & \\
\hline & & & $4-5$ & $1976-80$ & 4.4 & 7.6 & \\
\hline & & & & 1988-94 & 5.0 & 10.8 & \\
\hline \multirow[t]{4}{*}{ United States } & $\begin{array}{l}\text { National Health and } \\
\text { Nutrition Examination } \\
\text { Surveys }\end{array}$ & $\begin{array}{l}\text { US Centers for Disease } \\
\text { Control } 2000 \text { charts } \\
\text { (CDC 2000) [I35], >=95th } \\
\text { percentile }\end{array}$ & $6-11$ & $1976-80$ & 6.6 & 6.4 & $\begin{array}{c}\text { Baskin, Ard \& } \\
\text { Franklin et al, } 2005 \\
\text { [136] }\end{array}$ \\
\hline & & & & 1999-2002 & 16.9 & 14.7 & \\
\hline & & & $12-19$ & 1976-80 & 4.8 & 5.3 & \\
\hline & & & & 1999-2002 & 16.7 & 15.4 & \\
\hline \multirow[t]{2}{*}{ Canada } & $\begin{array}{l}\text { Nationally } \\
\text { representative surveys } \\
\text { (198I Canada Fitness } \\
\text { Survey; I996 National } \\
\text { Longitudinal Survey of } \\
\text { Children and Youth) }\end{array}$ & $\begin{array}{l}\text { International Obesity Task } \\
\text { Force (IOTF) [I37] } \\
\text { 'obesity' }\end{array}$ & $7-13$ & $198 \mid$ & 2.0 & 2.0 & $\begin{array}{c}\text { Tremblay, } \\
\text { Katzmarzyk \& } \\
\text { Willms, } 2002 \text { [138] }\end{array}$ \\
\hline & & & & 1996 & 10.0 & 9.0 & \\
\hline \multirow[t]{2}{*}{$\begin{array}{l}\text { Trinidad and } \\
\text { Tobago }\end{array}$} & $\begin{array}{l}\text { Nationally } \\
\text { representative cross- } \\
\text { sectional schools-based } \\
\text { survey }\end{array}$ & IOTF 'obesity' & $5-6$ & 1999 & 1.7 & 2.4 & $\begin{array}{c}\text { Gulliford, Mahabir } \\
\text { Rocke et al }(200 \mathrm{I}) \\
{[139]}\end{array}$ \\
\hline & & & $8-9$ & & 3.0 & 2.5 & \\
\hline Martinique & Schools-based surveys & IOTF 'obesity' & 14 & 1999 & 6.3 & 4.8 & $\begin{array}{l}\text { Benefice, Caiius \& } \\
\text { Garnier (2003) [140] }\end{array}$ \\
\hline \multicolumn{8}{|l|}{ South America } \\
\hline \multirow[t]{4}{*}{ Chile } & School census data & IOTF 'obesity' & 6 & 1987 & 1.8 & 2.1 & $\begin{array}{c}\text { Kain, Uauy \& Vio et } \\
\text { al, } 2002[141]\end{array}$ \\
\hline & & & & 2000 & 7.2 & 7.5 & \\
\hline & & $\begin{array}{l}\text { CDC } 2000>=95^{\text {th }} \\
\text { percentile }\end{array}$ & 6 & 1987 & 5.1 & 4.0 & \\
\hline & & & & 2000 & 14.7 & 15.8 & \\
\hline \multirow[t]{2}{*}{ Mexico } & Schools-based surveys & $\begin{array}{l}\text { CDC } 2000>=95^{\text {th }} \\
\text { percentile }\end{array}$ & $11-14$ & 1998-99 & 12.9 & 10.8 & $\begin{array}{c}\text { Salazar-Martinez, } \\
\text { Allen \& Fernandez- } \\
\text { Ortega et al (2006) } \\
\text { [142] }\end{array}$ \\
\hline & & & $15-19$ & & 8.0 & 4.9 & \\
\hline \multicolumn{8}{|l|}{ Australia } \\
\hline \multirow[t]{4}{*}{$\overline{\text { Australia }}$} & $\begin{array}{l}\text { National surveys (I985 } \\
\text { Australian Health \& } \\
\text { Fitness Survey; I995 } \\
\text { National Nutrition } \\
\text { Survey) }\end{array}$ & IOTF 'obesity' & $7-11$ & 1985 & 1.5 & 1.9 & $\begin{array}{l}\text { Magarey, Daniels \& } \\
\text { Boulton, 200I [143] }\end{array}$ \\
\hline & & & & 1995 & 3.7 & 6.3 & \\
\hline & & & $12-15$ & 1985 & 1.9 & 1.3 & \\
\hline & & & & 1995 & 6.1 & 4.4 & \\
\hline \multicolumn{8}{|l|}{ Europe } \\
\hline \multirow[t]{2}{*}{ England } & $\begin{array}{l}\text { National Study of Health } \\
\text { and Growth } \\
\text { (independent cross- } \\
\text { sectional surveys) }\end{array}$ & IOTF 'obesity' & $4-11$ & 1974 & 1.4 & 1.5 & $\begin{array}{c}\text { Chinn \& Rona, 200 I } \\
\text { [144] }\end{array}$ \\
\hline & & & & 1994 & 1.7 & 2.6 & \\
\hline \multirow[t]{2}{*}{ Scotland } & & & & 1974 & 1.7 & 1.9 & \\
\hline & & & & 1994 & 2.1 & 3.2 & \\
\hline
\end{tabular}


Table I: Examples of international obesity rates; different definitions, ages and dates - males and females (Continued)

\begin{tabular}{|c|c|c|c|c|c|c|c|}
\hline \multirow[t]{4}{*}{ England } & $\begin{array}{l}\text { Health Survey for } \\
\text { England }\end{array}$ & $\begin{array}{l}\text { United Kingdom (UK90) } \\
\text { charts }[145]>=95^{\text {th }} \\
\text { percentile }\end{array}$ & $2-10$ & 1995 & 9.6 & 10.3 & $\begin{array}{c}\text { National Health } \\
\text { Service Information } \\
\text { Centre, } 2006 \text { [146] }\end{array}$ \\
\hline & & & & 2004 & 16.2 & 11.9 & \\
\hline & & & $11-15$ & 1995 & 13.5 & 15.4 & \\
\hline & & & & 2004 & 23.7 & 26.2 & \\
\hline \multirow[t]{2}{*}{ Scotland } & Scottish Health Survey & UK90 > $=95^{\text {th }}$ percentile & $12-15$ & 1998 & 15.6 & 15.2 & $\begin{array}{c}\text { Scottish Public Health } \\
\text { Observatory, } 2007 \\
\text { [147] }\end{array}$ \\
\hline & & & & 2003 & 20.9 & 14.7 & \\
\hline \multirow[t]{4}{*}{$\begin{array}{l}\text { Northern } \\
\text { Ireland }\end{array}$} & Schools-based surveys & IOTF 'obesity' & 12 & $1989-90$ & 4.0 & 1.6 & $\begin{array}{c}\text { Watkins, Murray \& } \\
\text { McCarron et al, } 2005 \\
\text { [148] }\end{array}$ \\
\hline & & & & 2000 & 4.7 & 4.7 & \\
\hline & & & 15 & $1989-90$ & 0.4 & 3.9 & \\
\hline & & & & 2000 & 3.1 & 4.8 & \\
\hline \multirow[t]{2}{*}{ France } & Schools-based surveys & IOTF 'obesity' & $7-9$ & 2000 & 3.9 & 3.6 & $\begin{array}{l}\text { Rolland-Cachera, } \\
\text { Casetbon \& Arnault } \\
\text { et al, } 2002 \text { [149] }\end{array}$ \\
\hline & & $\begin{array}{l}\text { CDC } 2000>=95^{\text {th }} \\
\text { percentile }\end{array}$ & & & 7.5 & 5.2 & \\
\hline \multirow[t]{2}{*}{ Spain } & $\begin{array}{l}\text { Cross-sectional surveys } \\
\text { in randomly selected } \\
\text { schools }\end{array}$ & IOTF 'obesity' & $6-14$ & 1980 & 1.5 & 1.4 & Moreno, 200I [150] \\
\hline & & & & 1995 & 2.1 & 3.3 & \\
\hline Portugal & Schools-based surveys & IOTF' obesity' & 7-9 & $2002-03$ & 10.3 & 12.3 & $\begin{array}{l}\text { Padez, Fernandes \& } \\
\text { Mourao, } 2004 \text { [15I] }\end{array}$ \\
\hline \multirow[t]{2}{*}{ Italy } & $\begin{array}{l}\text { Schools-based surveys in } \\
\text { North }(N) \text { and South (S) } \\
\text { Italy }\end{array}$ & IOTF 'obesity' & $2-6$ & 2002 & $5.7(\mathrm{~N})$ & $5.8(\mathrm{~N})$ & $\begin{array}{c}\text { Maffeis, Consolaro \& } \\
\text { Cavarzere et al, } 2006 \\
\text { [152] }\end{array}$ \\
\hline & & & & & $12.3(\mathrm{~S})$ & $10.7(S)$ & \\
\hline \multirow[t]{2}{*}{ Sicily, Italy } & Schools-based surveys & IOTF 'obesity' & II & $|999-200|$ & 13.1 & 10.7 & $\begin{array}{c}\text { Baratta, Degano \& } \\
\text { Leonardi et al, } 2006 \\
\text { [153] }\end{array}$ \\
\hline & & & 15 & & 7.2 & 5.0 & \\
\hline \multirow[t]{2}{*}{ Greece } & Schools-based surveys & IOTF 'obesity' & $6-11$ & 1994 & 9.4 & 8.3 & $\begin{array}{c}\text { Papadimitriou, } \\
\text { Kounadi \& } \\
\text { Konstantinidou et al, } \\
2006 \text { [154] }\end{array}$ \\
\hline & & & & 2005 & 12.3 & 9.9 & \\
\hline Greece & Schools-based surveys & IOTF 'obesity' & $7-10$ & $2002-03 *$ & 16.0 & 13.4 & $\begin{array}{c}\text { Tokmakidis, } \\
\text { Kasambalis \& } \\
\text { Christodoulos, } 2006 \\
\text { [155] }\end{array}$ \\
\hline \multirow[t]{4}{*}{ Finland } & $\begin{array}{l}\text { Nationally } \\
\text { representative } \\
\text { Adolescent Health and } \\
\text { Lifestyle Survey }\end{array}$ & IOTF 'obesity' & 12 & 1977 & 2.0 & 0.9 & $\begin{array}{l}\text { Kautiainen, } 2005 \\
{[156]}\end{array}$ \\
\hline & & & & 2003 & 3.1 & 1.9 & \\
\hline & & & 16 & 1977 & 0.8 & 0.3 & \\
\hline & & & & 2003 & 4.2 & 2.1 & \\
\hline \multirow[t]{2}{*}{ Denmark } & $\begin{array}{l}\text { Nationally } \\
\text { representative samples }\end{array}$ & IOTF 'obesity' & $14-16$ & $197 \mid-72$ & 0.4 & 0.9 & $\begin{array}{c}\text { Kautiainen, } 2005 \\
\text { [156] }\end{array}$ \\
\hline & & & & $1996-97$ & 2.0 & 2.6 & \\
\hline \multirow[t]{4}{*}{ East Germany } & Schools-based surveys & IOTF 'obesity' & $5-7$ & 1992-93 & 4.7 & 3.5 & $\begin{array}{l}\text { Frye \& Heinrich, } \\
\quad 2003 \text { [157] }\end{array}$ \\
\hline & & & & 1998-99 & 2.7 & 4.8 & \\
\hline & & & $11-14$ & 1992-93 & 2.8 & 3.5 & \\
\hline & & & & 1998-99 & 7.1 & 7.9 & \\
\hline Poland & Schools-based surveys & IOTF 'obesity' & $7-9$ & 2001 & 3.6 & 3.7 & $\begin{array}{l}\text { Malecka-Tendera, } \\
\text { Klimek \& Matusik et } \\
\text { al, } 2005 \text { [158] }\end{array}$ \\
\hline \multirow[t]{2}{*}{ Russia } & $\begin{array}{l}\text { Nationally } \\
\text { representative } \\
\text { household survey }\end{array}$ & IOTF 'obesity' & $6-9$ & 1992 & 9.5 & 11.2 & $\begin{array}{c}\text { Wang \& Wang, } 2002 \\
{[159]}\end{array}$ \\
\hline & & & $10-18$ & & 2.4 & 1.3 & \\
\hline
\end{tabular}


Table I: Examples of international obesity rates; different definitions, ages and dates - males and females (Continued)

\begin{tabular}{|c|c|c|c|c|c|c|c|}
\hline & & $\begin{array}{l}\text { US Must, Dallal \& Dietz } \\
\text { I99| (MDD) charts [160], } \\
>=95^{\text {th }} \text { percentile }\end{array}$ & $6-9$ & & 13.2 & 15.9 & \\
\hline & & & $10-18$ & & 3.1 & 1.6 & \\
\hline \multirow[t]{2}{*}{ Russia } & $\begin{array}{l}\text { Nationally } \\
\text { representative } \\
\text { household surveys }\end{array}$ & $\begin{array}{l}\text { CDC } 2000>=95^{\text {th }} \\
\text { percentile }\end{array}$ & $7-13$ & 1995 & 6.2 & 3.0 & $\begin{array}{l}\text { Tudor-Locke, } \\
\text { Ainsworth \& Popkin, } \\
\text { in press [16I] }\end{array}$ \\
\hline & & & & 2002 & 4.2 & 3.1 & \\
\hline \multicolumn{8}{|l|}{ Africa } \\
\hline \multirow[t]{2}{*}{ Egypt } & Schools-based surveys & $\begin{array}{l}\text { CDC } 2000>=95 \text { th } \\
\text { percentile }\end{array}$ & $11-14$ & 1997 & 6.6 & 7.6 & $\begin{array}{c}\text { Salazar-Martinez, } \\
\text { Allen \& Fernandez- } \\
\text { Ortega et al, } 2006 \\
\text { [142] }\end{array}$ \\
\hline & & & $15-19$ & & 5.9 & 8.6 & \\
\hline Senegal & $\begin{array}{l}\text { Survey of members of } \\
\text { birth cohort }\end{array}$ & IOTF 'obesity' & $12-17$ & $1998-2000$ & 0.0 & 0.0 & $\begin{array}{l}\text { Benefice, Caiius \& } \\
\text { Garnier, } 2003 \text { [140] }\end{array}$ \\
\hline South Africa & Primary School Surveys & IOTF 'obesity' & 8 & $1994-95$ & 0.4 & 0.6 & $\begin{array}{l}\text { Jinabhai, Taylor \& } \\
\text { Sullivan, } 2003 \text { [162] }\end{array}$ \\
\hline \multicolumn{8}{|l|}{ Asia } \\
\hline Saudi Arabia & $\begin{array}{l}\text { Cross-sectional survey } \\
\text { of children from } \\
\text { randomly selected } \\
\text { households }\end{array}$ & IOTF 'obesity' & $1-18$ & 1994-98 & 6.0 & 6.7 & $\begin{array}{l}\text { El-Hazmi \& Warsy, } \\
2002 \text { [163] }\end{array}$ \\
\hline Qatar & Schools-based surveys & MDD $>=95^{\text {th }}$ percentile & 7 & 2002 & 1.6 & 5.4 & $\begin{array}{c}\text { Qotba \& Al-Isa, } 2007 \\
{[164]}\end{array}$ \\
\hline \multirow[t]{2}{*}{ Bahrain } & Schools-based surveys & IOTF 'obesity' & $12-17$ & 2000 & 14.9 & 17.9 & $\begin{array}{l}\text { Al-Sendi, Shetty \& } \\
\text { Musaiger, } 2003 \text { [165] }\end{array}$ \\
\hline & & MDD $>=95^{\text {th }}$ percentile & & & 16.5 & 20.2 & \\
\hline \multirow[t]{4}{*}{ Japan } & $\begin{array}{l}\text { Annual cross-sectional } \\
\text { household surveys }\end{array}$ & IOTF 'obesity' & $6-8$ & $1976-80$ & 1.8 & 1.8 & $\begin{array}{c}\text { Matsushita, Yoshiike } \\
\text { \& Kaneda et al, } 2004 \\
\text { [166] }\end{array}$ \\
\hline & & & & $1996-2000$ & 4.6 & 4.6 & \\
\hline & & & $12-14$ & $1976-80$ & 1.0 & 0.5 & \\
\hline & & & & $1996-2000$ & 2.7 & 1.0 & \\
\hline Korea & National survey & $>120 \%$ ideal body weight & $0-19$ & 2001 & I5.I & 10.2 & $\begin{array}{l}\text { Kim, Ahn \& Nam, } \\
2005 \text { [167] }\end{array}$ \\
\hline \multirow[t]{2}{*}{ Taiwan } & Schools-based surveys & $>120 \%$ ideal body weight & $12-15$ & $1980-82$ & 12.4 & 10.1 & Chu, 200I [168] \\
\hline & & & & $1994-96$ & 16.4 & II.I & \\
\hline \multirow[t]{4}{*}{ China - Beijing } & $\begin{array}{l}\text { Schools-based surveys in } \\
\text { Beijing (B) and Shanghai } \\
\text { (S) }\end{array}$ & $\begin{array}{l}\text { BMI classification } \\
\text { reference provided by } \\
\text { Working Group on } \\
\text { Obesity in China }\end{array}$ & $7-18$ & 1985 & $1.2(\mathrm{~B})$ & I.I (B) & Ji, 2007 [169] \\
\hline & & & & & I.I (S) & $0.4(S)$ & \\
\hline & & & & 2000 & $10.0(B)$ & $5.2(\mathrm{~B})$ & \\
\hline & & & & & $7.2(\mathrm{~S})$ & $4.1(S)$ & \\
\hline \multirow[t]{2}{*}{ China } & Schools-based surveys & IOTF 'obesity' & $13-14$ & 2002 & 2.6 & 1.5 & $\begin{array}{c}\text { Xie, Chou \& Spruijt- } \\
\text { Metz et al, } 2007 \\
{[170]}\end{array}$ \\
\hline & & & $16-17$ & & 4.3 & 1.0 & \\
\hline China & Schools-based surveys & IOTF 'obesity' & $11-17$ & 2004 & 5.0 & 2.1 & $\begin{array}{l}\text { Li, Dibley \& Sibbritt } \\
\text { et al, } 2006 \text { [32] }\end{array}$ \\
\hline Punjab, India & $\begin{array}{l}\text { Schools-based surveys of } \\
\text { children from affluent } \\
\text { families }\end{array}$ & IOTF 'obesity' & $6-11$ & $2002 *$ & 5.9 & 6.3 & $\begin{array}{c}\text { Sidhu, Kaur \& Kaur, } \\
2006[17 \mid]\end{array}$ \\
\hline India & Schools-based surveys & $\begin{array}{l}\text { Triceps skinfold thickness } \\
>=90^{\text {th }} \text { percentile }\end{array}$ & $9-15$ & $1998 *$ & 12.4 & 9.9 & $\begin{array}{c}\text { Chhatwal, Verma \& } \\
\text { Kaur, } 2004 \text { [172] }\end{array}$ \\
\hline
\end{tabular}

\footnotetext{
* survey dates provided by authors (personal communication).
} 
adolescents from 34 countries who self-reported height and weight in 2001-02 found the lowest rates in Lithuania and Latvia, and the highest in Malta and the United States. This study noted particularly high prevalences in countries in North America, Great Britain and south-western Europe [23]. A review of surveys conducted within Europe during the 1990s, suggested higher levels of childhood overweight and obesity in southern countries and lower levels in the central and eastern countries which experienced political and economic transition over that period [24]. Within developing countries, high prevalences are found in the Middle East [25].

Returning to Table 1, a further issue demonstrated is that of globally increasing rates, regardless of definition. Obesity has been described as the most common pediatric disease in most of the world, with the exceptions of subSaharan Africa and the former Soviet Union [26]. Within Europe, the prevalence rates of overweight and obesity are not rising at a constant rate, but are accelerating [27]. In respect of secular changes, what Table 1 cannot show is that in addition to increases in obesity rates, the distribution of BMI has become more skewed, with the greatest increases at the highest levels $[28,29]$. There is also evidence of changing body composition, with increasing fat and reductions in muscle [30,31].

In respect of gender, Table 1 suggests no consistent male or female excess. Differences are generally small, and there is no suggestion that either males or females consistently predominate within particular age groups, or according to particular definitions. Although international patterns are, in general, also difficult to discern, Table 1 suggests that within Asia, a male excess may exist in Korea, Taiwan and China, in contrast to a female excess in Middle Eastern countries. A proposal that the male excess in China may result from gender differences in child care associated with the one-child policy [32], has been challenged [33]. An apparent female excess in some UK studies using the IOTF definition is artefactual, since this definition has been shown to have lower sensitivity in UK males than females [34]. The study which derived $95^{\text {th }}$ BMI centiles for age and gender within its international adolescent sample found higher rates among males in some countries, while in others there was a female excess. However, in almost all cases the gender differences were not statistically significant [22]. Similarly, the review of surveys conducted within Europe in the 1990s found the number of countries with higher prevalences for overweight and obesity among females was almost the same as that with higher prevalences for males [24]. It is possible that gender differences may emerge in future; a study conducted in the US found significantly greater increases in rates among males between 1986-98 [35]. It has therefore been sug- gested that prevalence estimates for both males and females should always be presented [2].

While gender differences may be small overall, patterns may differ according to ethnic group. Among females, British studies almost always find the highest rates of obesity among black females, with the lowest levels generally found among South Asians [36,37]. Among a sample large enough to sub-divide into black African and black Caribbean groups, one UK study of 11-13 year olds found higher BMIs among both groups than in their white, Indian, Pakistani, Bangladeshi or mixed ethnicity peers [38]. These studies have generally found smaller, and less consistent ethnic differences in obesity rates among males. However, a US study found the same pattern among both males and females, the highest rates occurring in Mexican Americans at ages 6-11, and NonHispanic blacks at ages 12 to 17 [39]. Different results in respect of rates according to ethnicity by gender in studies conducted in the UK and US may result in part from the different groups included; there are few US data on the health and weight status of Asian Americans [40].

In respect of socioeconomic status (SES), studies suggest higher rates of obesity among low income groups in richer countries, and high income groups in poorer ones $[1,41]$. It is suggested that this is because in developing nations, higher SES individuals have become globalized, with easy access to relatively cheap, calorie-dense foods, while those of lower SES remain localized and undernourished [42]. Within the US, increases have also been greatest among children and adolescents from the lowest income families, so increasing SES disparities [35]. However, not all studies in developed countries find SES differences $[36,43,44]$, and among those that report separately, there is some evidence that SES differences may be clearer among females than males $[37,45]$.

\section{Causes}

\section{Genetic factors}

Like height, weight is heritable. One recent review suggests that twin and adoption studies point to a genetic contribution for BMI of 40-70\% [46], while a more extensive, but earlier, review of familial resemblance suggests that genetic factors explain $50-90 \%$ of BMI [47]. The results of genetic studies, where presented separately for males and females, appear broadly similar. Overall, the findings of such studies mean that genetic factors determine individual susceptibility to gain weight. Such 'thrifty' genes provide an evolutionary advantage in times of famine, when humans have to stockpile energy to survive, but a disadvantage when food is plentiful $[48,49]$. However, as several authors point out, while the propensity for obesity may have existed for a long time, the recent 
rapid rise in rates demonstrates the central role of environmental factors $[46,47,50]$.

\section{Behavioral factors}

Obesity is related to an imbalance between energy input and output, the size of which may be very small if over a long period [51]. One review suggests that in children, an imbalance of around $2 \%$, which is the equivalent of around 30 calories or 15 minutes of tv instead of play a day, may lead to obesity [52]. Behavioral determinants therefore include excess energy intake and/or inadequate energy expenditure [53], although the emphasis given to these 'Big Two', and the neglect of other plausible contributors to the secular increase in obesity has recently been questioned [54].

In respect of energy intake, dietary surveys do not suggest a secular increase among children and adolescents. However, the results of such studies may be confounded by an increasing trend towards greater under-reporting, to the extent that reported intake may be below the estimated required physiological minimum, especially among older girls. Regular consumption of high energy-dense fastfoods and sugary drinks which are associated with less satiation and so insufficient compensation via subsequent reductions in intake, increased portion size, eating outside the home and snacking have been particularly implicated in promoting weight gain. This is especially the case among older children, who are less influenced by biological cues of satiety $[50,55]$. In respect of energy expenditure and physical activity, assessment is difficult [56], and evidence for secular trends is scarce because of the absence of suitable baseline data [57]. However, a decline in UK adolescent energy intake from the 1930s to the 1980s with no concurrent change in body mass, increasingly pervasive electronic and screen-based entertainment, greater car travel and reduced walking or cycling, together with evidence of reductions in fitness in developed countries all point to lower activity levels [57-60].

Gender differences in many areas of nutrition emerge in childhood and adolescence. The greater fat-free mass of males, particularly post puberty, requires a higher energy intake. Thus the US Government suggests approximate daily requirements for moderately active $4-8$ year olds as being $1,500 \mathrm{kcal}$ for both males and females, compared with 2,600 kcal for males and 2,000 kcal for females aged 14-18 [61]. Studies of adolescents have found that females are more likely to pay attention to foods as a way to influence health and to meet nutritional recommendations, while males eat more fast foods. It has been suggested that these differences arise not only because of differences in Western societies' perception of ideal body weights, but also because some foods are gendered; for example meat may represent strength and virility. In addi- tion, the menstrual cycle has been associated with cravings for foods rich in fat and carbohydrate [12,62].

Gender differences in energy expenditure can also be attributed to both biological and social factors. Total energy expenditure (TEE) is strongly correlated with body weight, largely because of the relationship between resting energy expenditure and body weight [63]. Differences in body composition at puberty are associated with higher TEE among males than females, however there is limited and inconsistent data on male-female differences in TEE pre-pubertally $[63,64]$. Of all the components of TEE, physical activity is most amenable to modification [50], and a review of prospective observational studies has concluded that increased physical activity and decreased sedentary behavior protect against relative weight and fatness gains in childhood and adolescence [59].

It has been suggested that the clearest biological correlate of physical activity in children and adolescents is gender [65], and also that the effect of energy expenditure on the etiology of obesity may vary by gender, ethnicity or age $[51,52,63]$. Gender differences in physical activity begin in childhood. A longitudinal study found that while boys' daily TEE increased continuously between ages 5 and 10, that of girls increased from around $1,400 \mathrm{kcal}$ at 5 to $1,800 \mathrm{kcal}$ at 6 , but by age 9 had reduced to $1,600 \mathrm{kcal}$. This reduction was explained by a $50 \%$ reduction in physical activity between ages 6 and 9 [52]. One review cites data suggesting that levels of moderate or vigorous physical activities in US 11-12 year old boys are nearly twice those of girls, while age-related decreases in activity levels in adolescence are higher in girls. Thus a 1990 UK study found decreases between ages 11 and 18 in mean selfreport daily activity causing at least slight breathlessness from 83 to 57 minutes among males and from 49 to 26 among females. A review of the world literature suggested annual declines in physical activity of up to $2.7 \%$ among boys and $7.4 \%$ among girls between the ages of 10 and 17 $[56,65,66]$. Such findings have been related to differences in motor skills development, body composition, socialization towards sports and physical activity and freedom to engage in activities independently outside the home $[56,65]$.

Sedentary behavior has also been associated with body composition and BMI. For example, children who watch more tv have been shown to have higher skinfold thicknesses, while one study has suggested that approximately $17 \%$ of early adult overweight may be attributable to watching tv for two or more hours daily in childhood (reported in [57]). Given this, it is interesting that a review of studies of screen-based media use in contemporary youth, most from Europe or the US, found that males are also higher users of tv and video games. For example, 30\% 
of males and $25 \%$ of females watched tv for more than four hours a day, while 30\% males and $7 \%$ females played video games for more than four hours a week. This suggests that females may spend time in sedentary activities not measured by most current instruments [67].

\section{Parental influences}

Obesity clusters in families, and parental obesity is the most important risk factor for obesity in children [68]. While implicating genetic factors, the environments of children and, to a lesser extent, adolescents, are also generally provided by their parents $[69,70]$. There is evidence that familial patterns of adiposity may be partly attributable to similarities in diet. There is also evidence that selfregulation of energy intake by infants and children can be over-ridden by parental control, first among those who are formula fed and who may be encouraged to finish the bottle, then as well-meaning parents attempt to restrict children's eating. Gender differences have also been reported here: maternal restriction of snacks has been found to promote their over-consumption in an unrestricted setting by females, but not males; greater parental control has been linked to increased adiposity in females, but not males; mothers who use more control have been found to have daughters, but not sons, with poor energy regulation $[69,71,72]$. In addition, there is some evidence that parents are less likely to encourage sons to lose weight, perhaps because of the larger, more muscular ideal male body shape [73]. Parents also appear to be strong influences on physical activity in childhood, and again, there is evidence of gender differences; for example, stronger relationships with parental activity for girls $[65,74]$.

\section{Consequences}

Several reviews summarize the consequences, both shortand long-term, of childhood and adolescent obesity.

\section{Physical health consequences}

Childhood physical health consequences were, until fairly recently, largely unrecognized. In fact, there are few organ systems that severe obesity does not affect [1]. Associated outcomes include: cardiovascular risk factors, identified in children as young as 5 years; type 2 diabetes; non-alcoholic fatty liver disease; asthma; sleep-disordered breathing; systemic inflammation; and orthopedic problems. There is a marked tendency for obesity, particularly adolescent obesity, to track into adulthood, and so be associated with adult obesity-related disorders. However, even after controlling for current risk factors including weight, childhood obesity is associated with increased risk of allcause and coronary heart disease mortality $[1,2,75-80]$.

Some of the physical consequences of obesity are gendered, with some evidence that adult mortality risks are higher in respect of adolescent obesity among males $[75,76]$. There have been suggestions of a stronger relationship between obesity and asthma in females, but results in this respect are inconsistent $[81,82]$. Among females, obesity is associated with early onset of puberty and menarche which have, in turn, been linked to breast cancer, although the relationships are complex [83]. Obesity has also been related to other cancers of the female reproductive system, increased risk of spontaneous abortion and menstrual problems, particularly polycystic ovary syndrome which can lead to infertility $[1,11,12,49,68,84]$. The relationship between obesity and female puberty led to the suggestion that a threshold level of fatness is required for the female growth spurt and menarche. This is not now thought to be the case $[85,86]$; indeed, there is a growing body of evidence suggesting the opposite, that puberty effects levels of fatness [15].

Links have also been suggested between increasing levels of obesity, its association with female puberty and claims of recent reductions in age of menarche. Reviews conflict, some suggesting 'clear evidence' that the age of menarche is falling [87] and others that while menarche may be stable, the first signs of puberty, such as breast budding may now be occurring earlier $[85,86]$. However, it may be the case that there has been no recent secular change in either, but rather that obesity is associated with premature development of pubic hair and apparent breast tissue separate from true puberty [88].

Since markers of puberty are more overt and recordable for females, there is less information about its timing for males [87]. However, some reviews of obesity and puberty appear to extrapolate the female findings to males or children/adolescents in general $[68,85]$. In fact, although the evidence is much sparser, there is some evidence that in males, obesity is associated with later sexual maturation $[1,15,86]$.

\section{Psychosocial consequences}

The immediate psychosocial consequences of childhood and adolescent obesity have been long-recognized [89]. Stigmatization and discrimination by peers is well-documented; from very young ages, obese children are characterized in negative ways, less preferred as friends and more likely to be the targets of teasing or bullying $[1,2,75]$. There is also evidence of bias and stereotyping by teachers and even some parents [90]. While it could be argued that such behaviors might diminish as obesity becomes more commonplace, this does not appear to have occurred [1].

Evidence in respect of the psychological consequences of child and adolescent obesity is mixed [1]. While some reviews conclude that it is associated with psychological or psychiatric problems, increasing with age and particu- 
larly among girls [78], others suggest that research has failed to find consistent differences in the global selfesteem [91], depression or anxiety [92] of obese or overweight children and adolescents compared with the rest of the population. Such conflicting results may have arisen in part because obese clinic samples tend to have poorer psychological well-being and quality of life than community samples. While obese community samples have lower body satisfaction and physical self-competence than non-obese, few are depressed or have low global selfesteem $[93,94]$. Small differences in their psychological well-being may also be explained, at least partly, by weight-related teasing or bullying [95]. There have been suggestions of associations between depression and obesity, and that major depression in adolescents, or young females, predicts increased adult BMI $[95,96]$. However, the relationship between obesity and depression has been described as unproved [94].

Reductions in body satisfaction and well-being amongst the obese are greater among adolescents than children, and among females than males. Reflecting this, 12 of 18 recent studies of body dissatisfaction and 7 of 28 of selfesteem reported in one review included female participants only [94]. The consensus is that gender differences in body satisfaction emerge around 8-10 years of age [73]. While both males and females with a high BMI wish to be thinner, the picture is more complex for males because of the larger muscular male ideal. In relation to stereotypes and attitudes, some studies have demonstrated equivalent stereotyping of obese peers, regardless of gender. However others have suggested that females express stronger dislike of obese peers than males, and that obese females are rated more negatively than obese males. There is also some evidence that females may be more vulnerable to obesity-related victimization, but again, this is not a consistent finding $[90,97]$. The picture in relation to body satisfaction and obesity is also complicated by ethnic differences. For example, black girls with high BMIs are less likely than those from other ethnic groups to consider themselves overweight or desire to be thin $[90,98]$.

Gender differences in weight-control methods are also evident. Males are more likely to exercise, begin dieting at a higher BMI than females, and tend to focus on increasing upper body size while reducing fat [99]. In contrast to professionally administered, 'sensible' weight loss programs, [100], the use of unhealthy quick-fix dieting practices by some adolescents has been linked to a range of negative physiological and psychological outcomes $[101,102]$. Although such behaviors are significantly more likely among females [102,103], males are not immune to disordered eating behaviors $[99,104]$. The finding of one study that femininity as represented by selfascribed expressive personality traits, was predictive of eating problems among both male and female adolescents [105], highlights the need to consider such characteristics within each gender, rather than just compare the behaviors of males and females.

Finally, to return to the longer-term consequences, longitudinal studies in both the US and UK have demonstrated that child and adolescent obesity is associated with adverse social and economic outcomes such as reduced years of education, income and marriage rates in young adulthood. Again, there are gender differences, these effects being stronger for females $[1,2,75,76,78]$.

\section{Interventions}

The goal of any weight loss intervention is to achieve an energy imbalance so that intake is less than expenditure [77]. Most therefore target food consumption and/or physical activity either directly or indirectly [106]. A large number of reviews are now available, all focusing on the same, surprisingly small, evidence base. The majority conclude that: (a) treatment or prevention efforts have some positive effects, although these are generally small or very small; (b) a global approach, including various methods and settings, is likely to be more effective; and (c) given proper implementation and monitoring, there is little evidence of negative effects, either physiological or psychological. [70,77,80,100,106-122]. While some reviews have been unable to identify any particular interventions that characterize the positive studies [118], others have suggested that effective interventions can be distinguished on the basis of such factors as 'compulsory' aerobic physical activity [123], parental involvement [124] or more motivated participants $[121,125]$. Some authors have been more optimistic about the treatment of pediatric, as opposed to adult obesity, because of factors such as family support, and the fact that weight stabilization, rather than reduction, may be sufficient. Despite this, most pediatric obesity interventions are marked by relapse, although there is some evidence for long-term efficacy [107].

In respect of approaches, the most common include diets such as the traffic light diet (foods categorized as 'go', 'caution' and 'stop'), exercise sessions and increased general lifestyle activity, combined with the use of behavior change methods. For example, since obese children have a more negative perception of physical activity than nonobese children, and also find activity less reinforcing than sedentary behaviors, rewarding reductions in sedentary behaviors in order to increase physical activity has been found to be effective [107].

In respect of setting, a recent American Dietetic Association (ADA) position paper, based on a systematic evidence-based approach to the literature [106], categorized pediatric obesity interventions into three types; tertiary, 
secondary and primary, based on their target populations (the obese, those at risk of obesity and those with lower BMIs). In respect of tertiary prevention, limited evidence was found for individual-based interventions, but there was evidence that family-based interventions should be routinely recommended for 5-12 year olds, although less evidence to support similar recommendations for adolescents. School-based programs were recommended for primary prevention, and although equally effective for secondary prevention, were not recommended due to the risk of stigma among those targeted and because continually increasing rates of obesity suggest the need for population-wide approaches. Despite insufficient evidence to evaluate community-based approaches (for an extensive list of such policies see [126]), such interventions were recommended due to their potential to impact on the greatest numbers [106].

The ADA paper identified no studies which evaluated the efficacy of popular weight loss approaches, such as programs via the internet, in self-help formats or non commercial settings [106]. The internet has been identified as a potentially powerful tool for obesity intervention for a number of reasons, including its anonymity and accessibility. It has been suggested that it may be particularly successful among adolescents, given their high rates of internet use [127].

The ADA paper did not consider gender differences, however another recent review of the literature on the prevention and treatment of childhood obesity did [80]. Importantly, from the perspective of the current review, one of the gaps identified was that, along with immigrant and minority ethnic groups, and those aged below six years, males represented a population subgroup where obesity prevention programs and evidence of effectiveness were limited. In addition, it was noted that few programs were gender-specific.

There are a number of reasons why obesity prevention programs are more likely to be developed for girls, particularly adolescent girls [80]. As noted earlier, concerns about body image and vulnerability to eating disorders are greater, and participation in physical activity lower, among girls. However, this may have blinded those working in this field to the fact that the growing prevalence of obesity affects males and females equally. Further, genderspecific programs may be more effective than blanket approaches; some trials have found different effects for males compared with females $[77,115,128]$. Such evidence as there is suggests that males respond better to physical activity interventions [125]. It has been suggested that gender differences in the effects of interventions may become more apparent in adolescence, as biological and environmental differences increase $[129,130]$.
Despite such findings, a recent review of RCTs of exercise for treating obesity in children and adolescents found that not all trials described gender characteristics, and many which did reported combined results for males and females. Further, between-group differences in gender distribution and maturation stage tended not to be considered, despite their potential confounding effects on obesity outcomes [131]. Ignoring potential gender differences in effectiveness might result in failure to identify successful programs [122], while investigation of different effects for males and females might increase understanding of mechanisms of behavior change and optimize interventions [132].

\section{Conclusion}

Although not generally the principal focus of the literature on childhood and adolescent obesity, gender is a thread running through much of it. This review has highlighted the ways in which differences between males and females, both biological and those due to society or culture are relevant to obesity in childhood and adolescence. While the findings of genetic studies are broadly similar for males and females, and differences in obesity rates as defined by BMI are small and inconsistent, biological differences between males and females are apparent in the development of fat patterning and the association between levels of fat and health risks. Biological differences are also evident in respect of the female-limited consequences of obesity.

Biological and social factors merge in the development and impact of obesogenic behaviors, the long-term physical health consequences of the condition and the success of certain interventions. The greater fat-free mass of males is associated with greater energy expenditure and requirements, and differences between the bodies of males and females may impact on abilities to engage in certain physical or sporting activities. However, gender differences in food choices and dietary concerns, as well as those in overall physical activity levels are the result of social factors. Culture-bound conventions and roles determine these behaviors, with societal expectations and stereotypes for males and females being transmitted via parental, peer and media influences. Finally, social, rather than biological factors are evident in respect of gender differences in body satisfaction and the long-term psychosocial consequences of childhood and adolescent obesity. Being thin is highly valued in our Western society, but more so for females for whom it is associated with beauty, and poorer social or economic outcomes for obese females suggest gendered stigmatization and prejudice.

This review has also suggested that the patterning of child and adolescent obesity according to ethnicity or SES may differ for males compared with females. This highlights 
the importance of reporting not only overall prevalences, but also the socio-demographic patterning of obesity separately for males and females or, alternatively, noting that gender differences are absent. Studies which fail to do this, or which extrapolate from one gender to the other, may obscure differences which might help explain the distribution of obesity. One aim of this review was to identify gender differences within, as well as between males and females, for example in respect of masculine and feminine traits associated with obesity or behaviors. With one or two exceptions $[97,105]$, it appears that almost no attention has been paid to this area.

In sum, the evidence reviewed here suggests differences between males and females in both exposure and vulnerability to obesogenic environments, as well as in the consequences of obesity and responses to interventions. In doing so, it highlights the need for a clearer focus on gender differences within the field of childhood and adolescent obesity among both researchers and policy makers. To date, work in this area has tended to assume that the biological and social correspond [133], thus polarizing males and females. However, in relation to areas such as body image, self-esteem, dietary and exercise behaviors and interventions, it may be valuable to go further and to consider the impact of masculinity and femininity among both males and females.

\section{Acknowledgements}

The author would like to thank Professors Sally Macintyre, Nanette Mutrie, Patrick West and Charlotte Wright and Dr Seeromanie Harding for comments on an earlier draft. This paper is part of a series of Evidence Reviews on Gender and Health in the United Kingdom, funded in part by the European Men's Health Development Foundation. The author is funded by the UK Medical Research Council.

\section{References}

I. Lobstein T, Baur LA, Uauy R: Obesity in children and young people: a crisis in public health. Obesity Reviews 2004, 5(Suppl I): $4-85$.

2. Reilly JJ: Descriptive epidemiology and health consequences of childhood obesity. Best Practice \& Research Clinical Endocrinology \& Metabolism 2005, 19(3):327-34I.

3. Strock GA, Cottrell ER, Abang AE, Buschbacher RM, Hannon TS: Childhood obesity: a simple equation with complex variables. Journal of Long-Term Effects of Medical Implants 2005, I5(I): 15-32.

4. Bird C, Rieker P: Gender matters: an integrated model for understanding men's and women's health. Social Science and Medicine 1999, 48:745-755.

5. Krieger N: Genders, sexes, and health: what are the connections - and why does it matter? International Journal of Epidemiology 2003, 32:652-657.

6. Rutter M, Caspi A, Moffitt T: Using sex differences in psychopathology to study causal mechanisms: unifying issues and research strategies. Journal of Child Psychology and Psychiatry 2003, 44: $1092-1115$.

7. Jones AP, Remmington T, Williamson PR, Ashby D, Smyth RL: High prevalence but low impact of data extraction and reporting errors were found in Cochrane systematic reviews. Journal of Clinical Epidemiology 2005, 58(7):74|-742.
8. Power C, Laker S, Cole TJ: Measurement and long-term health risks of child and adolescent fatness. International Journal of Obesity 1997, 21:507-526.

9. Wabitsch M: Overweight and obesity in European children: definition and diagnostic procedures, risk factors and consequences for later health outcome. European Journal of Pediatrics 2000, I59:S8-SI3.

10. Goran MI, Gower BA: Relation between visceral fat and disease risk in children and adolescents. American Journal of Clinical Nutrition 1999, 70(I): 149S-156S.

II. Legato MJ: Gender-specific aspects of obesity. International Journal of Fertility \& Women's Medicine 1997, 42(3): I84-197.

12. Lovejoy JC: The influence of sex hormones on obesity across the female life span. Journal of Women's Health 1998, 7(10): 1247-1256.

13. Sweeting $\mathrm{H}$ : Measurement and definitions of obesity in childhood and adolescence: a field guide for the uninitiated. Nutrition Journal 2007, 6:32.

14. Prentice A, Jebb SA: Beyond body mass index. Obesity Reviews 200I, 2:I4I-I47.

15. Wang Y: Epidemiology of childhood obesity - methodological aspects and guidelines: what is new? International Journal of Obesity \& Related Metabolic Disorders: Journal of the International Association for the Study of Obesity 2004, 28(Suppl 3):S2I-28.

16. Reilly J, Wilson ML, Summerbell CD, Wilson DC: Obesity: diagnosis, prevention, and treatment; evidence based answers to common questions. Archives of Disease in Childhood 2002, 86:392-395.

17. Dietz WH, Bellizzi MC: Introduction: the use of body mass index to assess obesity in children. American Journal of Clinical Nutrition 1999, 70:I23S-I25S.

18. Troiano RP, Flegal KM: Overweight prevalence among youth in the United States: Why so many different numbers? International Journal of Obesity 1999, 23(Suppl 2):S22-S27.

19. Chinn S: Definitions of childhood obesity: current practice. European Journal of Clinical Nutrition 2006, 10: I I89-1 I 94.

20. James PT, Leach R, Kalamara E, Shayeghi M: The worldwide obesity epidemic. Obesity Research 200I, 9(Suppl 4):228S-233S.

21. Livingstone B: Epidemiology of childhood obesity in Europe. European Journal of Pediatrics 2000, I59(SuppI I):SI 4-34.

22. Lissau I, Overpeck M, Ruan J, Due P, Holstein B, Hediger M, Group atHBiS-aCOW: Body mass index and overweight in adolescents in 13 European countries, Israel and the United States. Archives of Pediatrics \& Adolescent Medicine 2004, 158:27-33.

23. Janssen I, Katzmarzyk P, Boyce W, Vereecken C, Mulvihill C, Robert C, Currie C, Pickett W: Comparison of overweight and obesity prevalence in school-aged youth from 34 countries and thier relationships with physical activity and dietary patterns. Obesity Reviews 2005, 6:123-132.

24. Lobstein T, Frelut M: Prevalence of overweight among children in Europe. Obesity Reviews 2003, 4:195-200.

25. Kelishadi R: Childhood overweight, obesity, and the metabolic syndrome in developing countries. Epidemiologic Reviews 2007, 29:62-76.

26. Reilly J: Obesity in childhood and adolescence: evidence based clinical and public health perspectives. Postgraduate Medical Journal 2006, 82:429-437.

27. Jackson-Leach R, Lobstein T: Estimated burden of pediatric obesity and co-morbidities in Europe. Part $\mathrm{I}$. The increase in the prevalence of child obesity in Europe is itself increasing. International Journal of Pediatric Obesity 2006, 1:26-32.

28. Jolliffe D: Extent of overweight among US children and adolescents from 197 I to 2000. International Journal of Obesity 2004, 28(I):4-9.

29. Flegal KM: Epidemiologic aspects of overweight and obesity in the United States. Physiology \& Behavior 2005, 86(5):599-602.

30. McCarthy HD, Ellis SM, Cole TJ: Central overweight and obesity in British youth aged II-16 years: cross sectional surveys of waist circumference. BMJ 2003, 326(7390):624.

3I. McCarthy HD, Jarrett KV, Emmett PM, Rogers I: Trends in waist circumferences in young British children: $A$ comparative study. International Journal of Obesity 2005, 29(2): 157-162.

32. Li M, Dibley M, Sibbritt $D$, Yan H: An assessment of adolescent overweight and obesity in Xi'an City, China. International Journal of Pediatric Obesity 2006, I:50-58. 
33. Yang J: China's one-child policy and overweight children in the 1 990s. Social Science and Medicine 2007, 64:2043-2057.

34. Reilly Jj, Dorosty AR, Emmett PM, Avon Longitudinal Study of Pregnancy and Childhood Study Team: Identification of the obese child: adequacy of the body mass index for clinical practice and epidemiology. International Journal of Obesity \& Related Metabolic Disorders: Journal of the International Association for the Study of Obesity 2000, 24(12):1623-1627.

35. Strauss R, Pollack H: Epidemic increase in childhood overweight. Journal of the American Medical Association 200I, 286:2845-2848.

36. Saxena S, Ambler G, Cole TJ, Majeed A: Ethnic group differences in overweight and obese children and young people in England: Cross sectional survey. Archives of Disease in Childhood 2004, 89(I):30-36.

37. Wardle J, Henning Brodersen N, Cole TJ, Jarvis M, Boniface D: Development of adiposity in adolescence: five year longitudinal study of an ethnically and socioeconomically diverse sample of young people in Britain. British Medical Journal 2006, 332:1130-1132.

38. Harding S, Maynard M, Cruickshank K, Gray L: Anthropometry and blood pressure differences in black Caribbean, African, South Asian and White adolescents: the MRC DASH study. Journal of Hypertension 2006, 24:1507-15 I4.

39. Troiano RP, Flegal KM: Overweight children and adolescents: description, epidemiology, and demographics. Pediatrics 1998 I 0 I(3 Pt 2):497-504.

40. Crawford PB, Story M, Wang MC, Ritchie LD, Sabry Zl: Ethnic issues in the epidemiology of childhood obesity. Pediatric Clinics of North America 200I, 48(4):855-878.

41. Wang Y: Cross-national comparison of childhood obesity: the epidemic and the relationship between obesity and socioeconomic status. International Journal of Epidemiology 200I, 30:1129-1136.

42. Sobal J: Commentary: Globalization and the epidemiology of obesity. International Journal of Epidemiology 200 I, 30:1 I 36-1 I 37.

43. Sobal J, Stunkard A]: Socio-economic status and obesity: a review of the literature. Psychological Bulletin 1989, 105:260-275.

44. Taylor S, Viner R, Booy R, Head J, Tate H, Brentnall S, Haines M, Bhui K, Hillier S, Stansfield S: Ethnicity, socio-economic status, overweight and underweight in East London adolescents. Ethnicity and Health 2005, 10:1 I3-128.

45. Zaninotto $P$, Wardle H, Stamatakis E, Mindell J, Head J: Forecasting obesity to 2010.2006 [http://www.dh.gov.uk/en/Publicationsand statistics/Publications/PublicationsStatistics/DH 4/38630]. London: Joint Health Surveys Unit - National Centre for Social Research and Department of Epidemiology and Public Health at the Royal Free and University College Medical School

46. Farooqi I: Genetic and hereditary aspects of childhood obesity. Best Practice \& Research Clinical Endocrinology \& Metabolism 2005, 19:359-374.

47. Maes HHM, Neale MC, Eaves LJ): Genetic and environmental factors in relative body weight and human adiposity. Behavior Genetics 1997, 27(4):325-35I.

48. Lev-Ran A: Human obesity: an evolutionary approach to understanding our bulging waistline. Diabetes/Metabolism Research Reviews 200I, 17(5):347-362.

49. Eshre Capri Workshop Group: Nutrition and reproduction in women. Human Reproduction Update 2006, I 2(3): 193-207.

50. Rennie K, Johnson L, Jebb SA: Behavioural determinants of obesity. Best Practice \& Research Clinical Endocrinology \& Metabolism 2005 , 19:343-358

5I. Reilly J, Ness A, Sherriff A: Epidemiological and physiological approaches to understanding the etiology of pediatric obesity: finding the needle in the haystack. Pediatric Research 2007, $61: 646-652$

52. Goran MI: Metabolic precursors and effects of obesity in children: a decade of progress, 1990-1999. American Journal of Clincal Nutrition 2001, 73:158-171.

53. Prentice A, Jebb SA: Obesity in Britain: gluttony or sloth? British Medical Journal 1995, 3 I I:437-439.

54. Keith S, Redden D, Katzmarzyk P, Boggiano M, Hanlon E, Benca R, Ruden D, Pietrobelli A, Barger J, Fontaine K, et al.: Putative contributors to the secular increase in obesity: exploring the roads less travelled. International Journal of Obesity 2006, 30:1585-1594.
55. Agras WS, Mascola AJ: Risk factors for childhood overweight. Current Opinion in Pediatrics 2005, 17(5):648-652.

56. Molnar D, Livingstone B: Physical activity in relation to overweight and obesity in children and adolescents. European Journal of Pediatrics 2000, I 59(Suppl I):S45-55.

57. Wareham NJ, van Sluijs EMF, Ekelund U: Physical activity and obesity prevention: a review of the current evidence. Proceedings of the Nutrition Society 2005, 64(2):229-247.

58. Dollman J, Norton K, Norton L: Evidence for secular trends in children's physical activity behaviour. British Journal of Sports Medicine 2005, 39:892-897.

59. Must A, Tybor DJ: Physical activity and sedentary behavior: a review of longitudinal studies of weight and adiposity in youth. International Journal of Obesity 2005, 29:S84-S96.

60. Canoy D, Buchan I: Challenges in obesity epidemiology. Obesity Reviews 2007, 8(suppl I): I-II.

6I. U.S. Department of Health and Human Services, U.S. Department of Agriculture: Dietary Guidelines for Americans, 2005. Washington DC: Government Printing Office; 2005.

62. Kiefer I, Rathmanner T, Kunze M: Eating and dieting differences in men and women. The Journal of Men's Health \& Gender 2005, 2(2): $|94-20|$.

63. Goran MI, Sun M: Total energy expenditure and physical activity in prepubertal children: recent advances based on the application of the doubly labeled water method. American Journal of Clinical Nutrition 1998, 68(4):944S-949S.

64. Muller MJ, Bosy-Westphal A: Assessment of energy expenditure in children and adolescents. Current Opinion in Clinical Nutrition \& Metabolic Care 2003, 6(5):519-530.

65. Kohl H, Hobbs K: Development of physical activity behaviors among children and adolescents. Pediatrics 1998, I 1 I:549-554.

66. Sallis P: Epidemiology of physical activity and fitness in children and adolescents. Critical Reviews in Food Science and Nutrition 1993, 33:403-408.

67. Marshall SJ, Gorely T, Biddle SJH: A descriptive epidemiology of screen-based media use in youth: A review and critique. Journal of Adolescence 2006, 29(3):333-349.

68. Shalitin S, Phillip M: Role of obesity and leptin in the pubertal process and pubertal growth - a review. International Journal of Obesity 2003, 27(8):869-874.

69. Birch LL, Fisher JO: Development of eating behaviors among children and adolescents. Pediatrics 1998, 101(3 II SUPPL):539-549.

70. Wardle J: Understanding the aetiology of childhood obesity: implications for treatment. Proceedings of the Nutrition Society 2005, 64:73-79.

7I. Faith MS, Scanlon KS, Birch LL, Francis LA, Sherry B: Parent-child feeding strategies and their relationships to child eating and weight status. Obesity Research 2004, I 2(II): I7I I-I 722.

72. Clark H, Goyder E, Bissell P, Blank L, Peters ]: How do parents' child-feeding behaviours influence child weight? Implications for childhood obesity policy. Journal of Public Health 2007, 29(2): |32-|4|.

73. Ricciardelli LA, McCabe MP: Children's body image concerns and eating disturbance: A review of the literature. Clinical Psychology Review 200I, 2 I(3):325-344.

74. Norton DE, Froelicher ES, Waters CM, Carrieri-Kohlman V: Parental influence on models of primary prevention of cardiovascular disease in children. European Journal of Cardiovascular Nursing 2003, 2(4):3II-322.

75. Dietz WH: Health consequences of obesity in youth: Childhood predictors of adult disease. Pediatrics 1998, IOI(3):518-525.

76. Dietz WH: Childhood weight affects adult morbidity and mortality. Journal of Nutrition 1998, I 28(2 Suppl):4I IS-4I4S.

77. Fulton JE, McGuire MT, Caspersen CJ, Dietz WH: Interventions for weight loss and weight gain prevention among youth - Current issues. Sports Medicine 200I, 3 I (3): I53-I65.

78. Reilly J], Methven E, McDowell ZC, Hacking B, Alexander D, Stewart L, Kelnar CJ: Health consequences of obesity. Archives of Disease in Childhood 2003, 88(9):748-752.

79. Clinton Smith J: The current epidemic of childhood obesity and its implications for future coronary heart disease. Pediatric Clinics of North America 2004, 5 I(6 SPEC. ISS): 1679- 1695.

80. Flynn MAT, McNeil DA, Maloff B, Mutasingwa D, Wu M, Ford C, Tough SC: Reducing obesity and related chronic disease risk 
in children and youth: a synthesis of evidence with 'best practice' recommendations. Obesity Reviews 2006, 7:7-66.

81. Chinn S: Obesity and asthma: evidence for and against a causal relation. Journal of Asthma 2003, 40(I): I-I6.

82. Chinn S: Obesity and asthma. Pediatric Respiratory Reviews 2006, 7:223-228.

83. Stoll BA: Teenage obesity in relation to breast cancer risk. International Journal of Obesity 1998, 22(II): 1035-1040.

84. Slyper AH: Childhood obesity, adipose tissue distribution, and the pediatric practitioner. Pediatrics 1998, 102(I):e4.

85. Dunger D, Ahmed ML, Ong K: Effects of obesity on growth and puberty. Best Practice \& Research Clinical Endocrinology \& Metabolism 2005, 19:375-390.

86. Slyper $\mathrm{AH}$ : The pubertal timing controversy in the USA, and a review of possible causative factors for the advance in timing of onset of puberty. Clinical Endocrinology 2006, 65(I): I-8.

87. Ebling F: Puberty: mind and body. Journal of Neuroendocrinology 2003, I 5(3):323-324.

88. Viner R: Is puberty getting earlier in girls? Archives of Disease in Childhood 2002, 86:10-12.

89. Bruch H: Obesity in childhood and personality development. American Journal of Orthopsychiatry 1941, I I:467-474.

90. Puhl R, Latner J: Stigma, obesity, and the health of the nation's children. Psychological Bulletin 2007, 133:557-580.

91. French S, Story M, Perry C: Self-esteem and obesity in children and adolescents: a literature review. Obesity Research 1995, 3:479-490

92. Friedman M, Brownell K: Psychological correlates of obesity: moving to the next research generation. Psychological Bulletin 1995, I 1 7:3-20.

93. Flodmark CE: The happy obese child. International Journal of Obesity 2005, 29:S3I-S33.

94. Wardle J, Cooke L: The impact of obesity on psychological well-being. Best Practice \& Research Clinical Endocrinology \& Metabolism 2005, I 9 (3 SPEC. ISS):42I-440.

95. McElroy SL, Kotwal R, Malhotra S, Nelson EB, Keck PE, Nemeroff CB: Are mood disorders and obesity related? A review for the mental health professional. Journal of Clinical Psychiatry 2004, 65(5):634-65I.

96. Stunkard AJ, Faith MS, Allison KC: Depression and obesity. Biological Psychiatry 2003, 54(3):330-337.

97. Pine KJ: Children's perceptions of body shape: a thinness bias in pre-adolescent girls and associations with femininity. Clinical Child Psychology and Psychiatry 200I, 6:5 19-536.

98. Bronner YL: Nutritional status outcomes for children: Ethnic, cultural, and environmental contexts. Journal of the American Dietetic Association 1996, 96(9):89|-903.

99. Robb AS, Dadson MJ: Eating disorders in males. Child and Adolescent Psychiatric Clinics of North America 2002, I I (2):399-4I8.

100. Butryn ML, Wadden TA: Treatment of overweight in children and adolescents: Does dieting increase the risk of eating disorders? International Journal of Eating Disorders 2005, 37(4):285-293.

10I. Potter BK, Pederson LL, Chan SSH, Aubut JA, Koval J]: Does a relationship exist between body weight, concerns about weight, and smoking among adolescents? An integration of the literature with an emphasis on gender. Nicotine \& Tobacco Research 2004, 6(3):397-425.

102. Daee A, Robinson P, Lawson M, Turpin JA, Gregory B, Tobias JD: Psychologic and physiologic effects of dieting in adolescents. Southern Medical Journal 2002, 95(9): 1032-104I.

103. Irving LM, Neumark-Sztainer D: Integrating the prevention of eating disorders and obesity: feasible or futile? Preventive Medicine 2002, 34(3):299-309.

104. Peixoto Labre M: Adolescent boys and the muscular male body ideal. Journal of Adolescent Health 2002, 30(4):233-242.

105. Wichstrom L: Social, psychological and physical correlates of eating problems. A study of the general adolescent population in Norway. Psychological Medicine 1995, 25:567-580.

106. American Dietetic Association, Ritchie LD, Crawford PB, Hoelscher D, Sothern MS: Position of the American Dietetic Association: individual-, family-, school-, and community-based interventions for pediatric overweight. Journal of the American Dietetic Association 2006, 106:925-945.

107. Epstein LH, Myers MD, Raynor H, Saelens BE: Treatment of pediatric obesity. Pediatrics 1998, I0I(3):554-570.
108. Ikeda JP, Mitchell RA: Dietary approaches to the treatment of the overweight pediatric patient. Pediatric Clinics of North America 200I, 48(4): $955-968$.

109. Nichols MR, Livingston D: Preventing pediatric obesity: assessment and management in the primary care setting. Journal of the American Academy of Nurse Practitioners 2002, 14(2):55-62. quiz 63-55.

110. Reilly J, McDowell ZC: Physical activity interventions in the prevention and treatment of paediatric obesity: systematic review and critical appraisal. Proceedings of the Nutrition Society 2003, 62(6II-6I9):

III. Fowler-Brown A, Kahwati LC: Prevention and treatment of overweight in children and adolescents. American Family Physician 2004, 69(II):259I-2598.

II2. Boon C, Clydesdale F: A review of childhood and adolescent obesity interventions. Critical Reviews in Food Science and Nutrition 2005, 45:5II-525.

I I3. Ells L, Campbell KJ, Lidstone J, Kelly S, Lang R, Summerbell CD: Prevention of childhood obesity. Best Practice \& Research Clinical Endocrinology \& Metabolism 2005, 19:44I-454.

I I4. Steinbeck K: Treatment options. Best Practice \& Research Clinical Endocrinology \& Metabolism 2005, 19:455-469.

II5. Summerbell CD, Waters E, Edmunds LD, Kelly S, Brown T, Campbell $\mathrm{KJ}$ : Interventions for preventing obesity in children. Cochrane Database of Systematic Reviews 2005(3):.

I 16. Collins C, Warren J, Neve M, McCoy P, Stokes B: Measuring effectiveness of dietetic interventions in child obesity. Archives of Pediatrics \& Adolescent Medicine 2006, 160:906-922.

117. DeMattia L, Lemont L, Meurer L: Do interventions to limit sedentary behaviours change behaviour and reduce childhood obesity? A critical review of the literature. Obesity Reviews 2006, 8:69-8I.

118. Flodmark CE, Marcus C, Britton M: Interventions to prevent obesity in children and adolescents: a systematic literature review. International Journal of Obesity 2006, 30:579-589.

119. Gibson L, Peto J, Warren J, dos Santos Silva I: Lack of evidence on diets for obesity for children: a systematic review. International Journal of Epidemiology 2006, 35: I544-1552.

120. Livingstone MB, McCaffrey T, Rennie K: Childhood obesity prevention studies: lessons learned and to be learned. Public Health Nutrition 2006, 9: I I 21-I I 29.

121. Stice E, Shaw H, Marti CN: A meta-analytic review of obesity prevention programs for children and adolescents: the skinny on interventions that work. Psychological Bulletin 2006, |32:667-691.

122. Thomas $\mathrm{H}$ : Obesity prevention programs for children and youth: why are their results so modest? Health Education Research 2006, $21: 783-795$.

123. Connelly J, Duaso M, Butler G: A systematic review of controlled trials of interventions to prevent childhood obesity and overweight: a realistic synthesis of the evidence. Public Health 2007, I 2 I(7):510-517.

124. Sharma M: International school-based interventions for preventing obesity in children. Obesity Reviews 2006, 8: I55-167.

125. Doak C, Visscher T, Renders C, Seidell J: The prevention of overweight and obesity in children and adolescents: a review of interventions and programmes. Obesity Reviews 2006, 7:111-136.

126. Lobstein T, Baur LA: Policies to prevent childhood obesity in the European Union. European Journal of Public Health 2005, I 5:576-579.

127. Zabinski M, Celio A, Wilfley DE, Taylor CB: Prevention of eating disorders and obesity via the internet. Cognitive Behaviour Therapy 2003, 32:137-150.

128. Stone EJ, McKenzie TL, Welk GJ, Booth ML: Effects of physical activity interventions in youth - Review and synthesis. American Journal of Preventive Medicine 1998, I5(4):298-315.

129. Epstein LH, Coleman KJ, Myers MD: Exercise in treating obesity in children and adolescents. Medicine and Science in Sports and Exercise 1996, 28(4):428-435.

130. Epstein LH, Paluch RA, Raynor H: Sex differences in obese children and siblings in family-based obesity treatment. Obesity Research 200I, 9:746-753.

13I. Atlantis E, Barnes EH, Singh MAF: Efficacy of exercise for treating overweight in children and adolescents: a systematic review. International Journal of Obesity 2006, 30(7): 1027-1040. 
132. Kremers S, de Bruijn G, Droomers M, van Lenthe F, Brug J: Moderators of environmental intervention effects on diet and activity in youth. American Journal of Preventive Medicine 2007, 32: $163-172$.

133. Clark J: Sexism, feminism and medicalism: a decade review of literature on gender and illness. Sociology of Health and IIIness 1983, 5:62-81.

134. Ogden CL, Troiano RP, Briefel R, Kuczmarski R, Flegal KM, Johnson $C:$ Prevalence of overweight among preschool children in the United States, I97I through 1994. Pediatrics 1997, 99(4):EI.

135. Kuczmarski RJ, Ogden CL, Grummer-Strawn LM, Flegal KM, Guo SS, Wei R, Mei Z, Curtin LR, Roche AF, Johnson CL: CDC Growth Charts: United States. In Advance data from vital and health statistics Volume 3/4. Hyattsville, Maryland: National Center for Health Statistics; 2000.

136. Baskin ML, Ard J, Franklin F, Allison DB: National prevalence of obesity: Prevalence of obesity in the United States. Obesity Reviews 2005, 6(I):5-7.

137. Cole TJ, Bellizzi MC, Flegal KM, Dietz WH: Establishing a standard definition for child overweight and obesity worldwide: international survey. British Medical Journal 2000, 320(7244): | 240- 1243.

138. Tremblay A, Katzmarzyk P, Willms J: Temporal trends in overweight and obesity in Canada, 1981-1996. International Journal of Obesity 2002, 26:538-543.

139. Gulliford M, Mahabir D, Rocke B, Chinn S, Rona RJ: Overweight, obesity and skinfold thicknesses of children of African or Indian descent in Trinidad and Tobago. International Journal of Epidemiology 2001, 30:989-998.

140. Benefice E, Caiius N, Garnier D: Cross-cultural comparison of growth, maturation and adiposity indices of two contrasting adolescent populations in rural Senegal (West Africa) and Martinique (Caribbean). Public Health Nutrition 2003, 7:479-485.

14I. Kain J, Uauy R, Vio F, Albala C: Trends in overweight and obesity prevalence in Chilean children: comparison of three definitions. European Journal of Clinical Nutrition 2002, 56(3):200-204.

142. Salazar-Martinez E, Allen B, Fernandez-Ortega C, Torres-Mejia G, Gala O, Lazcano-Ponce E: Overweight and obesity status among adolescents from Mexico and Egypt. Archives of Medical Research 2006, 37:535-542.

143. Magarey AM, Daniels LA, Boulton TJ: Prevalence of overweight and obesity in Australian children and adolescents: reassessment of 1985 and 1995 data against new standard international definitions. Medical Journal of Australia 200I, I 74( I I):56 I-564.

144. Chinn S, Rona RJ: Prevalence and trends in overweight and obesity in three cross sectional studies of British Children, I 974-94. BMJ 200I, 322(7277):24-26.

145. Cole TJ, Freeman JV, Preece MA: Body mass index reference curves for the UK, 1990. Archives of Disease in Childhood 1995, 73(I):25-29.

146. Information Centre for Health and Social Care: Health Survey for England 2004. Updating of trend tables to include childhood obesity data. [http://www.ic.nhs.uk].

147. Scottish Public Health Observatory: Obesity in Scotland. An epidemiology briefing. 2007 [http://www.scotpho.org.uk/home/Pub lications/scotphoreports/pub obesityinscotland.asp]. Edinburgh: Scottish Public Health Observatory

148. Watkins DC, Murray LJ, McCarron P, Boreham CAG, Gran GW, Young IS, McGartland C, Robson PJ, Savage JM: Ten-year trends for fatness in Northern Irish adolescents: The Young Hearts Projects - Repeat cross-sectional study. International Journal of Obesity 2005, 29(6):579-585.

149. Rolland-Cachera MF, Casetbon K, Arnault N, Bellisle F, Romano M, Lehingue $Y$, Frelut $M$, Hercberg S: Body mass index in 7-9-y-old French children: frequency of obesity, overweight and thinness. International Journal of Obesity 2002, 26:1610-1616.

150. Moreno LA: Prevalence and trends in childhood obesity in Zaragoza (Spain) (Rapid response to Chinn and Rona, 322, 24-26). British Medical Journal 2001.

I5I. Padez C, Fernandes T, Mourao I, Moreira P, Rosado V: Prevalence of overweight and obesity in 7-9 year old Portuguese children: trends in body mass index from 1970-2002. American Journal of Human Biology 2004, 16:670-678.

152. Maffeis C, Consolaro A, Cavarzere P, Chini L, Banzato C, Grezzani A, Silvagni D, Salzano G, De Luca F, Tato L: Prevalence of overweight and obesity in 2- to 6-year old Italian children. Obesity 2006, I 4:765-769.

153. Baratta R, Degano C, Leonardi D, Vigneri R, Frittitta L: High prevalence of overweight and obesity in II-I5 year old children from Sicily. Nutrition, Metabolism \& Cardiovascular Diseases 2006, I 6:249-255.

154. Papadimitriou A, Kounadi D, Konstantinidou M, Xepapadaki P, Nicolaidou P: Prevalence of obesity in elementary schoolchildren living in Northeast Attica, Greece. Obesity 2006, I4: I I I3- I I I 7.

155. Tokmakidis S, Kasambalis A, Christodoulos A: Fitness levels of Greek primary schoolchildren in relationship to overweight and obesity. European Journal of Pediatrics 2006, 165:867-874.

156. Kautiainen S: Trends in adolescent overweight and obesity in the Nordic countries. Scandinavian Journal of Nutrition/Naringsforskning 2005, 49(I):4-I4.

157. Frye $\mathrm{C}$, Heinrich J: Trends and predictors of overweight and obesity in East German children. International Journal of Obesity 2003, 27:963-969.

I58. Malecka-Tendera E, Klimek K, Matusik P, Olszanecka-Glinianowicz M, Lehingue Y: Obesity and overweight prevalence in Polish 7-9 year old children. Obesity Research 2005, I 3:964-968.

I59. Wang Y, Wang J: A comparison of international references for the assessment of child and adolescent overweight and obesity in different populations. European Journal of Clinical Nutrition 2002, 56:973-982.

160. Must A, Dallal GE, Dietz WH: Reference data for obesity: 85th and 95th percentiles of body mass index $\left(\mathrm{wt} / \mathrm{ht}^{2}\right)$ and triceps skinfold thickness. American Journal of Clinical Nutrition 1991, 53:839-846.

16I. Tudor-Locke C, Ainsworth BE, Popkin BM: Patterns of physical activity and overweight among 7-13 year old Russian children: a seven-year nationally representative monitoring study. Research Quarterly for Exercise and Sport in press. In press for Volume 79, scheduled March 2008.

162. Jinabhai CC, Taylor M, Sullivan KR: Implications of the prevalence of stunting, overweight and obesity amongst South African primary school children: a possible nutritional transition? European Journal of Clinical Nutrition 2003, 57(2):358-365.

163. El-Hazmi M, Warsy A: A comparative study of prevalence of overweight and obesity in children in different provinces of Saudi Arabia. Journal of Tropical Pediatrics 2002, 48: I72-I77.

164. Qotba H, Al-Isa A: Anthropometric measurements and dietary habits of schoolchildren in Qatar. International Journal of Food Sciences \& Nutrition 2007, 58: I-5.

165. Al-Sendi A, Shetty P, Musaiger A: Prevalence of overweight ad obesity among Bahraini adolescents: a comparison between three different sets of criteria. European Journal of Clinical Nutrition 2003, 57:47I-474.

166. Matsushita Y, Yoshiike N, Kaneda F, Yoshita K, Takimoto H: Trends in childhood obesity in Japan over the last $\mathbf{2 5}$ years form the National Nutrition Survey. Obesity Research 2004, I 2:205-2 4.

167. Kim D, Ahn C, Nam S: Prevalence of obesity in Korea. Obesity Reviews 2005, 6:117-121.

168. Chu NF: Prevalence and trends of obesity among school children in Taiwan - the Taipei Children Heart Study. International Journal of Obesity 2001, 25:170-176.

169. Ji C: Report on childhood obesity in China (4) Prevalence and trends of overweight and obesity in Chinese urban schoolage children and adolescents, 1985-2000. Biomedical and Environmental Sciences 2007, 20:1-10.

170. Xie B, Chou C, Spruijt-Metz D, Reynolds K, Clark F, Palmer P, Gallaher P, Sun P, Guo Q, Johnson C: Socio-demographic and economic correlates of overweight status in Chinese adolescents. American Journal of Health Behavior 2007, 3 I:339-352.

17I. Sidhu S, Kaur N, Kaur R: Overweight and obesity in affluent school children of Punjab. Annals of Human Biology 2006, 33:255-259.

172. Chhatwal J, Verma M, R K: Obesity among pre-adolescent and adolescents of a developing country (India). Asia Pacific Journal of Clinical Nutrition 2004, I 3:23 I-235. 